\title{
The Changing Face of Arctic Snow Cover: A Synthesis of Observed and Projected Changes
}

\author{
Terry V. Callaghan, Margareta Johansson, Ross D. Brown, Pavel Ya. Groisman, \\ Niklas Labba, Vladimir Radionov, Roger G. Barry, Olga N. Bulygina, \\ Richard L. H. Essery, D. M. Frolov, Vladimir N. Golubev, Thomas C. Grenfell, \\ Marina N. Petrushina, Vyacheslav N. Razuvaev, David A. Robinson, \\ Peter Romanov, Drew Shindell, Andrey B. Shmakin, Sergey A. Sokratov, \\ Stephen Warren, Daquing Yang
}

\begin{abstract}
Analysis of in situ and satellite data shows evidence of different regional snow cover responses to the widespread warming and increasing winter precipitation that has characterized the Arctic climate for the past 40-50 years. The largest and most rapid decreases in snow water equivalent (SWE) and snow cover duration (SCD) are observed over maritime regions of the Arctic with the highest precipitation amounts. There is also evidence of marked differences in the response of snow cover between the North American and Eurasian sectors of the Arctic, with the North American sector exhibiting decreases in snow cover and snow depth over the entire period of available in situ observations from around 1950, while widespread decreases in snow cover are not apparent over Eurasia until after around 1980. However, snow depths are increasing in many regions of Eurasia. Warming and more frequent winter thaws are contributing to changes in snow pack structure with important implications for land use and provision of ecosystem services. Projected changes in snow cover from Global Climate Models for the 2050 period indicate increases in maximum SWE of up to $15 \%$ over much of the Arctic, with the largest increases (15-30\%) over the Siberian sector. In contrast, SCD is projected to decrease by about $10-20 \%$ over much of the Arctic, with the smallest decreases over Siberia $(<10 \%)$ and the largest decreases over Alaska and northern Scandinavia (30-40\%) by 2050 . These projected changes will have far-reaching consequences for the climate system, human activities, hydrology, and ecology.
\end{abstract}

Electronic supplementary material The online version of this article (doi:10.1007/s13280-011-0212-y) contains supplementary material, which is available to authorized users.
Keywords Snow depth - Snow water equivalent . Snow cover duration $\cdot$ Snow cover extent

\section{INTRODUCTION}

Frozen precipitation accumulating on a surface creates a snow cover. Snow is an important and dominant feature of Arctic terrestrial landscapes with cover present for 8-10 months of the year. Its extent, dynamics, and properties (e.g., depth, density, water equivalent, grain size, and changes in structure throughout its vertical profile) affect climate (e.g., ground thermal regime), human activities (e.g., transportation, resource extraction, water supply, use of land, and ecosystem services), as well as infrastructure, hydrological processes, permafrost, extreme events (including hazards such as avalanches and floods), biodiversity, and ecosystem processes. Snow is therefore a significant component in the socio-economics of Arctic societies. The important physical properties that exert an influence on climate or moderate its effects (Cohen and Rind 1991) include high short-wave albedo, high thermal emissivity, low heat conductivity, large latent heat of fusion, and low surface roughness while it stores and rapidly releases water in the melt season. The combination of high albedo and low thermal conductivity promotes low surface temperatures and low-level temperature inversions. The low thermal conductivity of snow allows it to insulate the surface from large energy losses in winter, and this has major implications for the development of seasonally frozen ground and permafrost.

The characteristics of Arctic snow cover are the result of a complex interplay of atmospheric and surface processes that determine not only the quantity of water stored as snow, but also snowpack condition (e.g., grain size, 
density, and ice layers). The amount of snow accumulating on a surface is influenced by precipitation amount, type, and timing; blowing snow transport and sublimation; and vegetation interception. However, the character and evolution of high-latitude snowpack has the additional complexity of being particularly strongly dependent on blowing snow processes with the distribution and physical properties of snow on the ground closely linked to local-scale variability in terrain and vegetation (King et al. 2008). The key large-scale physiographic and climatic factors influencing the regional distribution of Arctic snow cover (see On-line supplementary material Fig. A) are elevation, amount of vegetation cover, spatial distribution of freezing temperatures, and location of the main cyclone tracks bringing moisture into the Arctic. Air temperature and elevation exert the strongest influences on the distribution of snow cover duration (SCD) across the Arctic (Fig. Ae) with both continents exhibiting marked east-west increases in snow cover in response to the modification of winter air masses over the cold, dry continental interiors. Land areas in the zone of $-20^{\circ} \mathrm{C}$ mean winter temperatures (see darker blue area in Fig. Ac) experience snow cover for most of the year. The spatial distribution of snow water equivalent (SWE; the depth of liquid water that would result from melting the snow) is more complex than SCD but is basically driven by moisture availability over the snow season, reflected in the cyclone frequency map (Fig. Ad). The highest snow accumulations in the Arctic are located in the coastal mountain regions and considerably more moisture penetrates into the western sector of the Eurasian Arctic than North America, where the coastal mountains block moisture entering from the Pacific Ocean. Regions with winter temperatures closer to freezing, such as Scandinavia and the Pacific coasts of Russia and Alaska, are also more likely to experience thaw and rain-on-snow events that create ice layers in the snowpack.

The high winds, low temperatures and low snowfall amounts over the exposed tundra regions of the Arctic produce a snow cover that is typically quite shallow, about $30-40 \mathrm{~cm}$ (except in drifts and gullies), with a wind-hardened surface layer ("wind slab") overlying a less dense depth hoar ("sugar snow") layer (Derksen et al. 2010). The average snow density remains close to $300 \mathrm{~kg} \mathrm{~m}^{-3}$ over much of the snow season, but snow depth and properties can exhibit strong local variation with many exposed areas, drifts, dunes, and zastrugi (sharp irregular ridges on the snow surface formed by wind erosion and deposition). In forested regions of the Arctic (taiga and boreal forest), snow cover is more uniform and less dense $\left(\sim 200 \mathrm{~kg} \mathrm{~m}^{-3}\right)$ as the trees act as windbreaks and shade the snow from incoming solar radiation in the spring (McKay and Gray 1981). In contrast, north of the tree line, where wind action compacts the snow, snow density is higher.
Because the Arctic's snow cover is strongly related to temperature and moisture as described above, past (Walsh et al. 2011a, b [this issue]) and projected changes in the Arctic's temperature and precipitation are likely to result in changes in the characteristics of the Arctic's snow cover with far-reaching impacts on the climate system (Callaghan et al. 2011a, b [this issue]), human activities, as well as infrastructure, hydrological processes, permafrost, extreme events (including hazards such as avalanches and floods), biodiversity, and ecosystem processes (AMAP 2011; Callaghan et al. 2011b [this issue]). This article assesses current and projected changes in the Arctic's snow cover. It is part of a larger assessment of the Arctic's entire cryosphere (AMAP 2011; Callaghan et al. 2011b [this issue]).

\section{CURRENT CHANGES IN SOLID PRECIPITATION}

There is a wide range of regularly observed snow cover information in the Arctic from in situ and satellite observations. The SCD on the ground is one of the best-observed variables in terms of resolution and longevity. Snow depth and SWE are more difficult to monitor due to their high spatial variability, large gaps in the in situ observing networks, and difficulties in monitoring from satellites. The indigenous peoples of the Arctic have a profound knowledge of changing snow conditions of practical importance for survival, which has been passed from generation to generation, and the Sáme observe snow stratigraphy that is important for reindeer access to vegetation (Riseth et al. 2010).

In the Atlantic, North European, and West Siberian sectors, the climatic conditions are formed largely under the influence of heat and moisture advection from the North Atlantic area. Climate in the East Siberian and Chukchi sectors is significantly influenced by circumpolar conditions over the northern Pacific Ocean, as well as by the center of action above Siberia (see Fig. 1 for definition of the sectors). The Alaskan sector is also influenced by circumpolar processes over the northern Pacific Ocean. In the Canadian sector, the climatic conditions in winter are governed both by anticyclonic circulation above northwestern Canada and the Arctic Basin and by the frequent passage of Alberta lows and Atlantic east coast systems.

Analysis of trends in seasonal totals of precipitation from October to May (which correspond to the snowfall season with mean monthly temperatures below $-2^{\circ} \mathrm{C}$ ) at climate stations located north of $60^{\circ} \mathrm{N}$ revealed an increase in cold season precipitation between 1936 and 2009 in almost all sectors of the Arctic (Table 1; see also Figs. B and $\mathrm{C}$ in the On-line supplementary material).

The analysis is based on monthly total precipitation data collected at the stations from the start of their operation up 
Fig. 1 Long term meteorological stations in the Arctic (red dots) and mean monthly location of North Pole drifting stations (blue dots) in different sectors of the Arctic. 1-Atlantic; 2-NorthEuropean; 3-West-Siberian; 4-East-Siberian; 5-Chukchi; 6-Alaskan; 7-Canadian

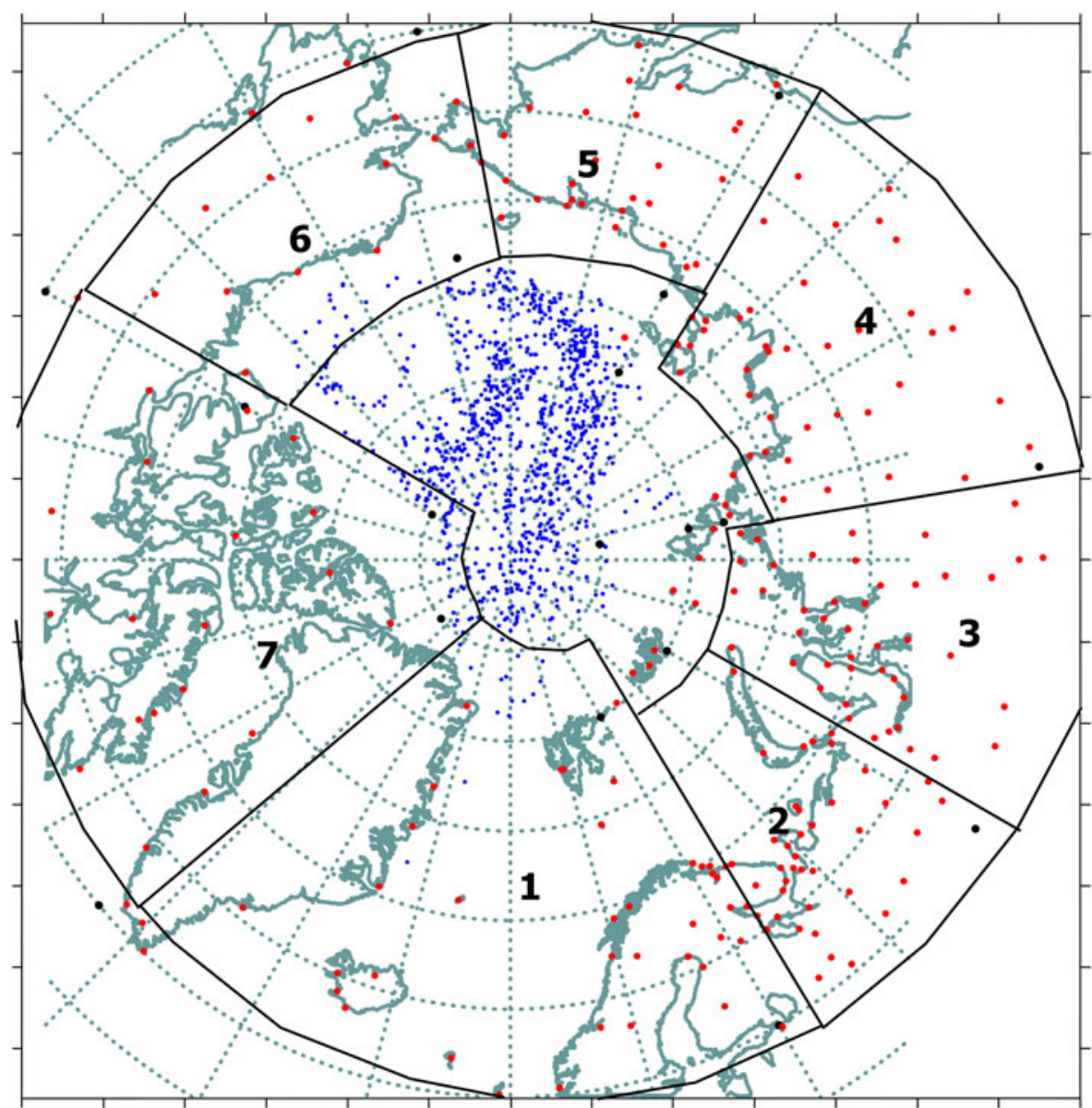

to 2009. Regionally averaged series were calculated over the latitudinal zones from $60^{\circ}$ to $70^{\circ} \mathrm{N}, 70^{\circ}$ to $85^{\circ} \mathrm{N}$, and $60^{\circ}$ to $85^{\circ} \mathrm{N}$ using a method of optimal averaging for the seven sectors shown in Table 1 (Frolov 2009). Canadian results were computed from a 2008 update of the adjusted and homogenized precipitation dataset of Mekis and Hogg (1999), but there were insufficient station data in the Canadian Arctic sector north of $70^{\circ} \mathrm{N}$ to compute trends in the $70^{\circ}-85^{\circ} \mathrm{N}$ and $60^{\circ}-85^{\circ} \mathrm{N}$ sectors before 1939 (Fig. 1).

\section{Snow Depth, Snow Water Equivalent, Snow Cover Duration and Extent}

There have been long-term increases in winter snow depth over northern Scandinavia and Eurasia (Kohler et al. 2006; Bulygina et al. 2009; Fig. 2, also Fig. D in the Online supplementary material) but significant decreases over the North American Arctic between 1950 and 2006 (Fig. 3; updated from Atkinson et al. 2006). Similarly, SWE increased over Eurasia and most of northern Russia for the 1966-2009 period (Bulygina et al. 2010a), but decreased over northern Canada over the 1966-1996 period
(Atkinson et al. 2006). This contrast is surprising as both continents have experienced long-term increases in cold season precipitation (Table 1; Figs. B and C in the Online supplementary material; Trenberth et al. 2007; Min et al. 2008). Over most of Russia, the number of days with snow depth greater than $20 \mathrm{~cm}$ has increased (Fig. E in the Online supplementary material). In the northern and southern regions of Western Siberia, in Yakutia, and on the coast of the Sea of Okhotsk, the trend is 8-10 days per decade. In contrast, the Chukchi Peninsula and Transbaikalia has experienced a decrease of days with snow depth greater than $20 \mathrm{~cm}$ by 6-10 days per decade (Bulygina et al. 2009). Trends in SCD also contrast between the two Arctic regions (Figs. 2, 3) until after 1980 when the trends over Eurasia also began to decline. Maximum decreases in SCD of the order of 4-6 days per decade were found in the western and southern regions of European Russia from 1951 to 2006 (Kitaev et al. 2006; Razuvaev and Bulygina 2006; Bulygina and Razuvaev 2008; Shmakin 2010). In contrast, there is an increase in the duration of snow cover recorded in Yakutia (central northern Siberia) and in some regions of the Russian Far East, owing to their proximity to the Pacific Ocean. 
Table 1 Linear trend analysis (least-squares method) for cold season (October-May) total precipitation over the long term (1936-2009) and short term (1980-2009)

\begin{tabular}{|c|c|c|c|c|c|c|c|c|c|c|c|c|c|c|c|c|c|c|}
\hline \multirow[t]{3}{*}{ Areas } & \multicolumn{6}{|c|}{$60-70^{\circ} \mathrm{N}$} & \multicolumn{6}{|c|}{$70-85^{\circ} \mathrm{N}$} & \multicolumn{6}{|c|}{$60-85^{\circ} \mathrm{N}$} \\
\hline & \multicolumn{3}{|c|}{ 1936-2009 } & \multicolumn{3}{|c|}{ 1980-2009 } & \multicolumn{3}{|c|}{ 1936-2009 } & \multicolumn{3}{|c|}{ 1980-2009 } & \multicolumn{3}{|c|}{ 1936-2009 } & \multicolumn{3}{|c|}{ 1980-2009 } \\
\hline & $B_{x}$ & $\begin{array}{l}\Delta \\
(\%)\end{array}$ & $\begin{array}{l}r^{2} \\
(\%)\end{array}$ & $B_{x}$ & $\begin{array}{l}\Delta \\
(\%)\end{array}$ & $\begin{array}{l}r^{2} \\
(\%)\end{array}$ & $B_{x}$ & $\begin{array}{l}\Delta \\
(\%)\end{array}$ & $\begin{array}{l}r^{2} \\
(\%)\end{array}$ & $B_{x}$ & $\begin{array}{l}\Delta \\
(\%)\end{array}$ & $\begin{array}{l}r^{2} \\
(\%)\end{array}$ & $B_{x}$ & $\begin{array}{l}\Delta \\
(\%)\end{array}$ & $\begin{array}{l}r^{2} \\
(\%)\end{array}$ & $B_{x}$ & $\begin{array}{l}\Delta \\
(\%)\end{array}$ & $\begin{array}{l}r^{2} \\
(\%)\end{array}$ \\
\hline $\begin{array}{l}\text { Atlantic } \\
\qquad\left(50^{\circ} \mathrm{W}-30^{\circ} \mathrm{E}\right)\end{array}$ & 9.2 & 8.2 & 22.2 & -13.7 & -4.8 & 13.0 & 9.1 & 28.6 & 46.7 & 10.1 & 12.9 & 27.1 & 9.1 & 10.3 & 30.8 & -5.5 & -2.6 & 7.4 \\
\hline $\begin{array}{l}\text { North European } \\
\left(30^{\circ} \mathrm{E}-60^{\circ} \mathrm{E}\right)\end{array}$ & 16.2 & 40.0 & 70.8 & 7.9 & 7.8 & 19.0 & 6.2 & 20.3 & 50.9 & 9.9 & 13.1 & 29.8 & 12.1 & 33.0 & 73.8 & 9.0 & 9.9 & 30.9 \\
\hline $\begin{array}{l}\text { West Siberian } \\
\left(60^{\circ} \mathrm{E}-100^{\circ} \mathrm{E}\right)\end{array}$ & 10.3 & 28.5 & 65.4 & 1.2 & 1.3 & 4.5 & -0.2 & $0-1.1$ & 1.9 & 17.1 & 38.6 & 65.2 & 5.9 & 20.6 & 59.0 & 7.9 & 11.2 & 37.3 \\
\hline $\begin{array}{l}\text { East Siberian } \\
\left(100^{\circ} \mathrm{E}-150^{\circ} \mathrm{E}\right)\end{array}$ & 3.1 & 15.0 & 41.3 & 4.5 & 8.8 & 26.4 & -3.5 & -21.2 & 38.8 & 1.0 & 2.5 & 5.2 & 0.6 & 2.7 & 9.7 & 3.1 & 6.7 & 22.3 \\
\hline $\begin{array}{l}\text { Chukchi } \\
\left(150^{\circ} \mathrm{E}-170^{\circ} \mathrm{W}\right)\end{array}$ & -0.2 & -0.7 & 1.3 & -6.9 & -9.5 & 24.8 & -8.4 & -42.3 & 56.4 & -3.3 & -6.7 & 17.3 & -3.4 & -12.8 & 24.3 & -5.5 & -8.7 & 29.3 \\
\hline $\begin{array}{l}\text { Alaskan } \\
\left(170^{\circ} \mathrm{W}-140^{\circ} \mathrm{W}\right)\end{array}$ & 2.5 & 10.9 & 15.1 & 0.0 & 0.0 & 0.0 & -0.4 & -6.6 & 3.6 & 10.1 & 67.8 & 44.1 & 2.0 & 9.4 & 14.7 & 1.7 & 3.4 & 5.4 \\
\hline $\begin{array}{l}\text { Canadian }^{\mathrm{a}} \\
\left(140^{\circ} \mathrm{W}-60^{\circ} \mathrm{W}\right)\end{array}$ & 6.3 & 23.1 & 26.9 & 8.1 & 11.7 & 8.1 & 8.5 & 54.2 & 28.7 & 2.9 & 7.6 & 0.8 & 7.8 & 30.7 & 40.3 & 10.0 & 16.5 & 17.0 \\
\hline $\begin{array}{l}\text { Whole latitudinal } \\
\text { zone }^{\mathrm{b}}\end{array}$ & 5.7 & 14.5 & 27.2 & 0.1 & 0.1 & 0.0 & 1.8 & 10.5 & 7.4 & 5.8 & 13.7 & 12.1 & 3.6 & 10.9 & 20.6 & 3.7 & 4.7 & 5.2 \\
\hline
\end{tabular}

$\overline{B_{x}}$, trend in mm per decade; $\Delta$, linear change over the period as a percentage of the 1961-1990 mean; $r^{2}$, percentage of variance explained by linear regression

See Fig. 1 for definitions of the sectors. Values in bold are significant at the confidence level $p \leq 0.10$

${ }^{a}$ For Canada the adjusted and homogenized precipitation dataset of Mekis and Hogg (1999, updated to 2008) was used. Data are available from 1936 to 2008 for $60-70^{\circ} \mathrm{N}$, but there are no data prior to 1939 for $70-85^{\circ} \mathrm{N}$ (and $60-85^{\circ} \mathrm{N}$ )

${ }^{\mathrm{b}}$ for non-overlapping sectors weighted by land area for $1936-2008$ for $60-70^{\circ} \mathrm{N}$ and $1939-2008$ for $70-85^{\circ} \mathrm{N}$ and $60-85^{\circ} \mathrm{N}$

A general increase in duration of the period with snow on the ground over Russia and the Russian polar region north of the Arctic Circle by 5 days (3\%) and 12 days (5\%), respectively, over the period 1936-2004 was reported by Groisman et al. (2006). Linear trend analyses applied to the entire period of observations available for their study lead to the paradoxical conclusion that the increase in snow duration could not be associated with "Arctic warming," which was not apparent over this particular time period.

In the coastal zone of the Eurasian Arctic, the interannual variability of dates of formation and decay of continuous snow cover is large, varying by 1.5 months. The duration of the period with continuous snow cover varies from 200 to 300 days at different stations in this zone (Radionov et al. 2004). In the Fennoscandian and AlaskanCanadian sector there has been a statistically significant decrease of about 3 days per decade in SCD (Table 2). In contrast, an increase by 1.5 days per decade was detected in the Kara Sea sector. During the past three decades (1978-2007), there has been a statistically significant decrease in SCD in coastal and island areas in all sectors of the Arctic (ranging from 4 to 9 days per decade) except for the Kara Sea and the Chukchi Sea sectors (Table 2).
The NOAA satellite record shows that variability in SCD in the North American and Eurasian Arctic has been more or less in phase since observations began in 1966, with contrasting seasonal patterns of little change in autumn SCD (i.e., the snow cover onset date) while spring SCD (i.e., the snow-off date) underwent a rapid decrease during the 1980s (Fig. 4). Foster et al. (2008) attributed this step change to a regime change in the Arctic Oscillation (AO) to more positive values. However, a new multidataset study of spring snow cover changes over the Arctic (Brown et al. 2010) suggested that the reduction in spring snow cover is more linear over time and has a closer link to Arctic temperature trends than to the AO. The asymmetric seasonal response of SCD is consistent with observed warming trends that are likely being enhanced by positive snow-albedo feedbacks (Groisman et al. 1994a; Déry and Brown 2007).

The trend (days per decade) in the dates of the onset and disappearance of continuous snow cover over the coastal region of northern Russia for the 1973-2003 period shows great variability but a slight tendency for later formation of snow cover in autumn and for an earlier reduction of snow cover in spring (Fig. F in the On-line supplementary material). Negative values indicate a later date of formation 

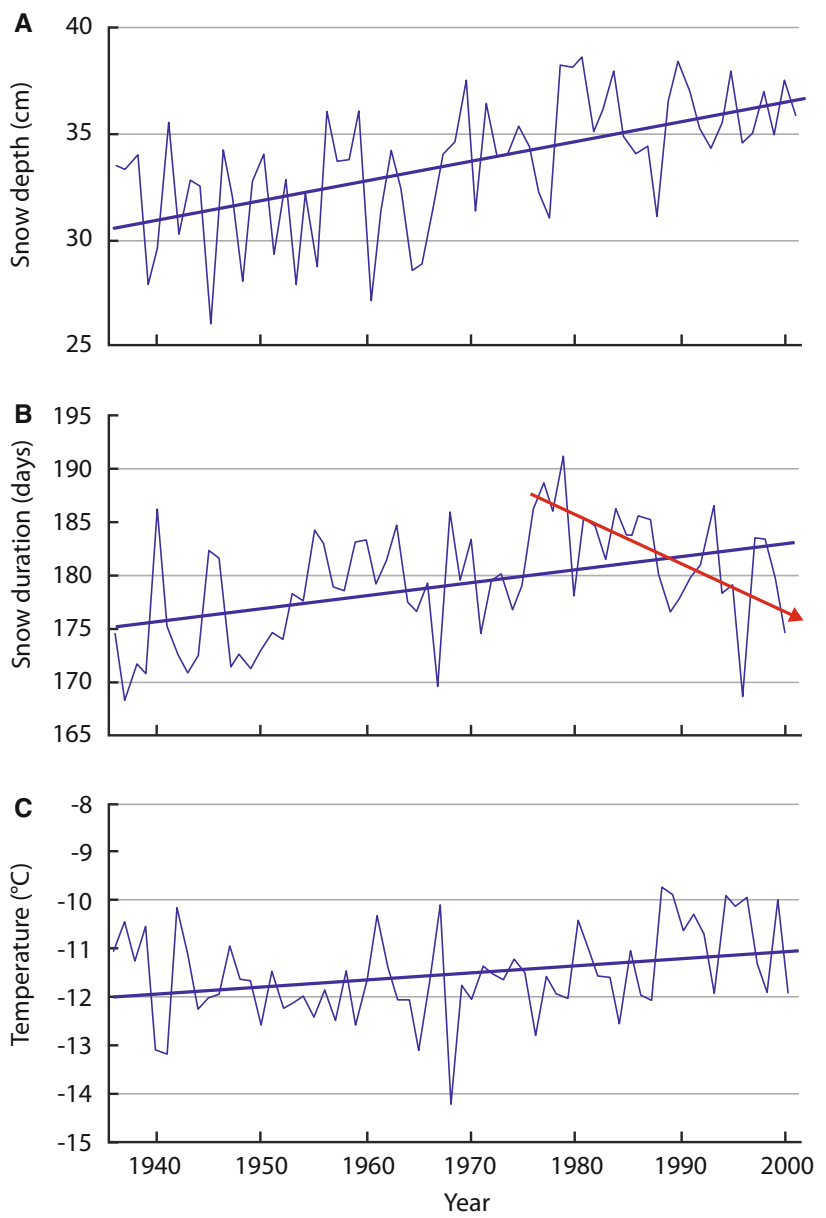

Fig. 2 Long-term variability in northern Eurasia (1936-2004) of a mean February snow depth, $\mathbf{b}$ the number of days where $50 \%$ or more of the land surface is snow covered, and $\mathbf{c}$ winter temperature (November-May). Solid lines indicate linear trends (Kitaev et al. 2005); the red line is an ad hoc indication of recent decreases in the number of days with snow cover in contrast to the long-term trend (modified from Kitaev et al. 2005) and copyright AMAP, 2011

or decay of snow cover in comparison with the long-term average date (Radionov et al. 2004).

Data from satellite imagery show that Arctic snow cover extent in May-June decreased by an average of $18 \%$ over the 1966-2008 period of the NOAA (National Oceanic and Atmospheric Administration, the United States Department of Commerce) record. Spatial analysis of snow cover trends in the NOAA dataset (Fig. 5) confirms a number of the previously mentioned characteristics. Specifically, that decreases are more marked in the snow cover melt period than the snow cover onset period, that the date of snow cover onset has become earlier over northern Russia, and that spring decreases over Eurasia tend to be stronger in northern coastal regions. The average change in SCD over the panArctic region (excluding Greenland) was -0.49 days per decade in the snow cover onset period, and -3.43 days per decade in the spring snow cover melt period (Fig. 5).
Arctic indigenous peoples have also observed longterm changes in snow conditions as these have direct impacts on their livelihoods (Forbes and Stammler 2009; Bartsch et al. 2010). However, their observations are at the local scale, and few are published. Also, most of their observations relate to changes in snow structure and their impacts on the mobility of reindeer and reindeer herders as well as access to vegetation. Observations on snow cover by the Sámi from northern Sweden highlight recent increases in ice crusts and in some areas snow accumulation, with statements such as "all valleys were snow free during (reindeer) calving in the 1930s", "terrain elements that determined animal movements in the summer are now snow covered: reindeer now find new passes and roam over a wider area", "snow-covered areas and snow patches persist longer into the summer in high mountain areas", and "rapid thaws created problems when moving to summer grazing areas in 1938-1940" (Riseth et al. 2010). Many of these observations match or add to nearby climate station monitoring, particularly for the period up to the 1990s (Callaghan et al. 2010).

Arctic snow cover exhibits large interannual variability, linked to large-scale variation in atmospheric circulation, around the previously documented trends. For example, the increase in snow depth over most of northern Eurasia in recent decades can be explained in two ways. First, there was a dramatic retreat in Arctic sea ice at the end of the warm season (Serreze et al. 2007) that left large ice-free or thin-ice areas at the beginning of the cold season in the Eurasian sector of the Arctic Ocean. These allowed additional water vapor influx into the dry Arctic atmosphere that ended up as snowfall further south. Second, more intensive cyclonic circulation and more frequent cyclones (Popova 2004) related to changes in atmospheric circulation also caused increased snow depth over most of northern Eurasia in recent decades. This circulation change is linked to significant increases in the North Atlantic Oscillation (NAO) index since the 1970s (Popova 2007). Snow accumulation in Eurasia is also strongly modulated by the Scandinavian pattern (SCAND) that reflects the intensity of blocking anticyclones in Eastern Europe. Snow accumulation is negatively correlated with the SCAND index, and in the 1951-1975 period, was the most important circulation pattern influencing variation in snow depth across Eurasia (Popova 2007). The Pacific North America (PNA) and Pacific Decadal Oscillation (PDO) have been shown to influence climate and snow cover over the western Canadian Arctic (Derksen et al. 2008b) with positive (negative) modes of the PNA and PDO associated with reduced (increased) snow accumulation and a shorter (longer) snow cover season. 
Fig. 3 Variability and change in North American Arctic snow cover from the 1950/19512006/2007 snow season.

a Annual SCD. b Annual maximum snow depth. Values are regionally averaged anomalies from 23 stations (14 from Canada, 9 from Alaska) with anomalies calculated with respect to a 1971-2000 reference period. The least squares linear trend lines shown are both statistically significant (0.05 level) with slopes of -2.8 days/decade and $-1.9 \mathrm{~cm} /$ decade. Source: updated from Atkinson et al. (2006)
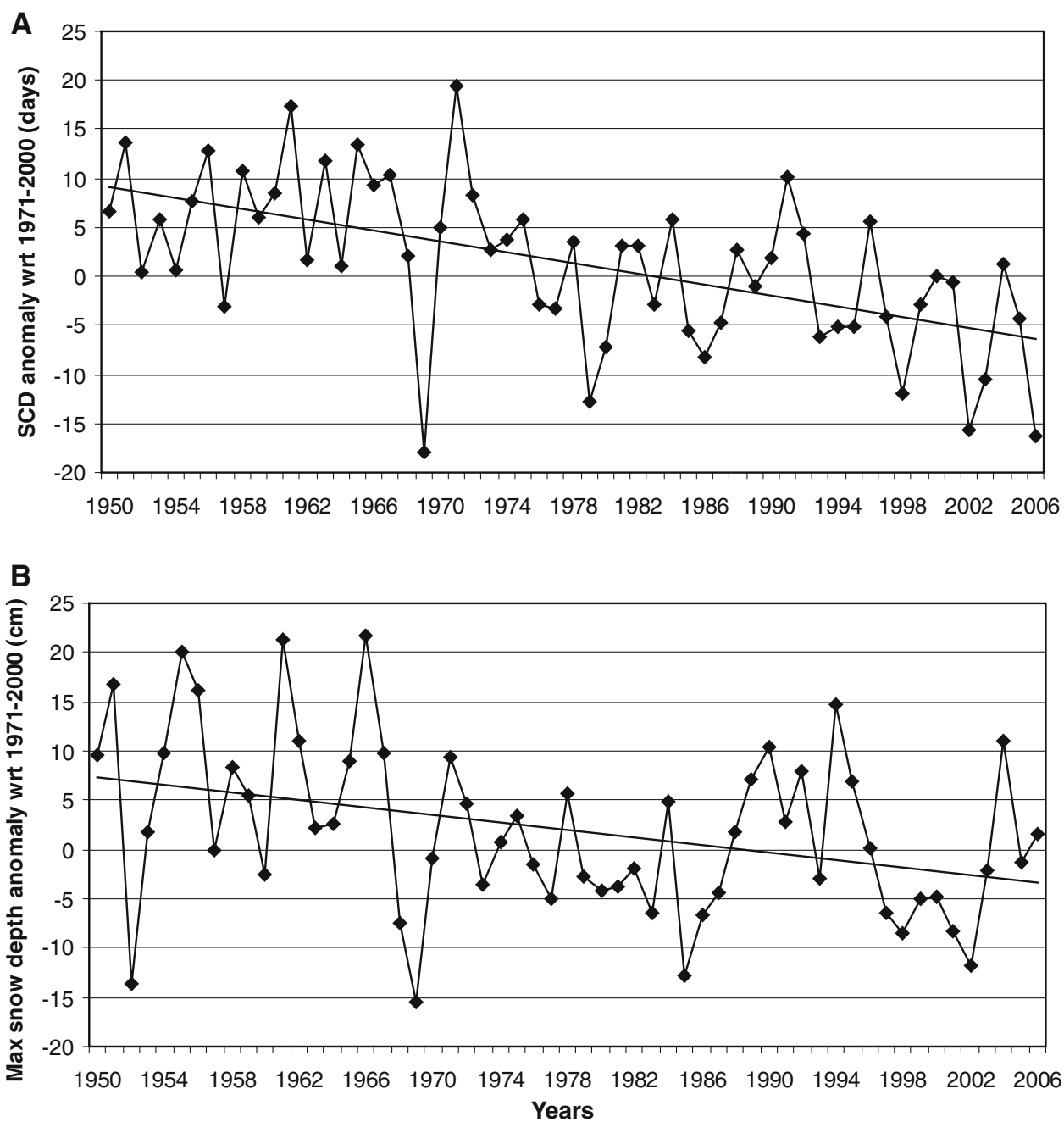

Table 2 Results of linear trend analysis (using least-squares method) of continuous SCD from regionally averaged in situ observations in coastal and island areas of the Arctic from 1951 to 2007

\begin{tabular}{|c|c|c|c|c|c|c|c|}
\hline Parameter & $\begin{array}{l}\text { Fennoscandia } \\
\text { sector }\end{array}$ & $\begin{array}{l}\text { Barents Sea } \\
\text { sector }\end{array}$ & $\begin{array}{l}\text { Kara Sea } \\
\text { sector }\end{array}$ & $\begin{array}{l}\text { Laptev Sea } \\
\text { sector }\end{array}$ & $\begin{array}{l}\text { East-Siberian Sea } \\
\text { sector }\end{array}$ & $\begin{array}{l}\text { Chukchi Sea } \\
\text { sector }\end{array}$ & $\begin{array}{l}\text { Alaska and Canada } \\
\text { sector }^{\mathrm{a}}\end{array}$ \\
\hline \multicolumn{8}{|l|}{ 1951-2007 } \\
\hline$B_{x}$ & -3.5 & -0.6 & 1.5 & -0.3 & 1.8 & 0.3 & $-\mathbf{3 . 0}$ \\
\hline$\Delta(\%)$ & -10.3 & -1.7 & 3.2 & -0.6 & 3.8 & 0.6 & -6.7 \\
\hline$r^{2}(\%)$ & 48.0 & 9.2 & 29.5 & 6.5 & 22.3 & 4.9 & 33.2 \\
\hline \multicolumn{8}{|l|}{ 1978-2007 } \\
\hline$B_{x}$ & -7.3 & -6.3 & 1.0 & -5.4 & -8.7 & -3.0 & -4.1 \\
\hline$\Delta(\%)$ & -11.5 & -9.4 & 1.1 & -6.0 & -10.0 & -3.7 & -4.8 \\
\hline$r^{2}(\%)$ & 54.1 & 50.1 & 11.3 & 68.3 & 60.6 & 30.2 & 29.0 \\
\hline
\end{tabular}

Values in bold are significant at the 0.05 significance level

$B_{x}$, coefficient of linear trend, number of days per decade; $\Delta$, linear change over period as a percentage of the 1961-1990 mean; $r^{2}$, percentage of variance explained by linear trend). Source: updated from Radionov et al. (2004a)

Defined by Radionov et al. (1996) as the duration of the period with continuous snow cover (50\% or more of the visible area is reported as 'snow covered')

${ }^{a}$ Computed from Canadian and Alaskan daily snow depth data with SCD defined as the number of days in the snow season with daily snow depths $\geq 2 \mathrm{~cm}$ following Brown and Goodison (1996) 


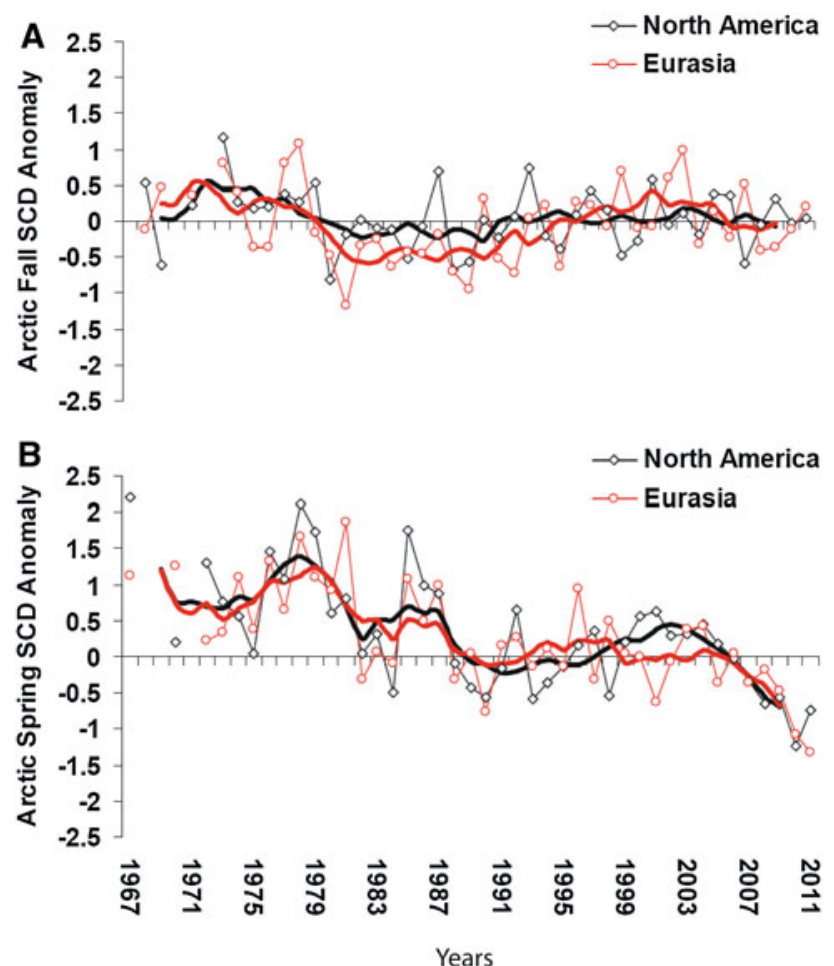

Fig. 4 Time series of SCD anomalies for the North American and Eurasian Arctic (relative to the mean for 1966-2007) from the NOAA record for the a first half (autumn) and $\mathbf{b}$ second half (spring) of the snow season. Solid lines denote the 5-year moving average. Source: updated from Derksen et al. (2009)
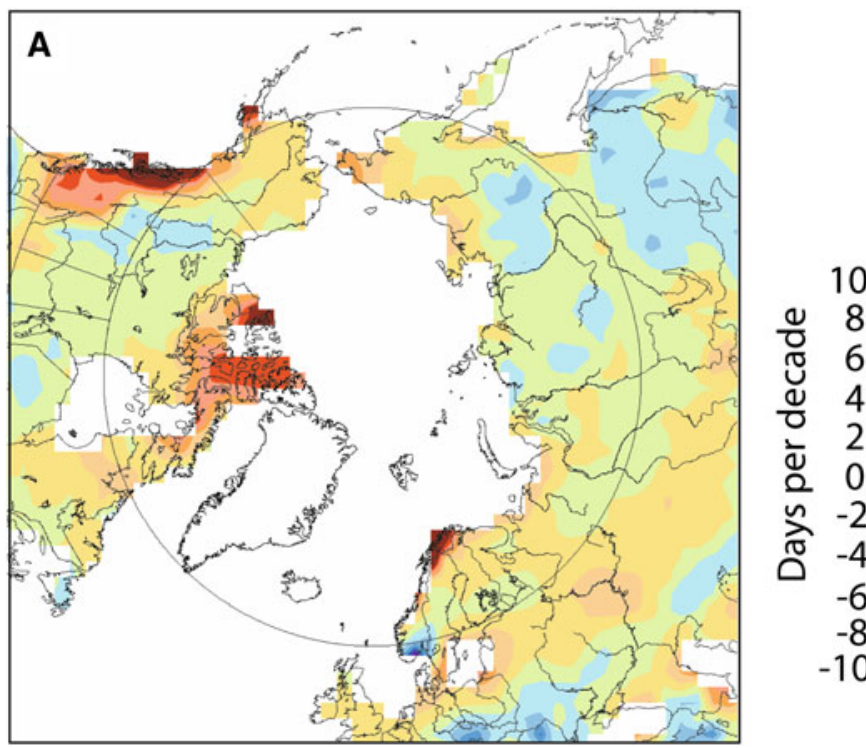

Fig. 5 Trend in SCD (days per decade) for a autumn (snow cover onset period) and b spring (snow cover melt period) over the 1972/1973-2008/2009 snow seasons from the NOAA weekly dataset maintained at Rutgers University by Dr. D. Robinson. Trends were

\section{Changes in Snow Properties}

\section{Snow Structure and Snow Cover Stratigraphy}

Data on trends in snow cover stratigraphy are rare (but see Bulygina et al. 2010b, for data relating to Russia; Riseth et al. 2010 and Johansson et al. 2011, for data relating to Sweden; and Gerland et al. 1999, for data related to Svalbard). Nevertheless, they are important for example in determining animal access to food beneath snow, while the presence of weak layers (depth hoar) or slip planes (crusts or ice layers) in the snowpack increases the potential for avalanche release. Sámi traditional knowledge from the Abisko area of sub-Arctic Sweden reports several local changes in the physical properties of the snow cover, particularly the development since the 1980s of more snow and ice layers in the snowpack that are hard for the reindeer to penetrate (Riseth et al. 2010). Furthermore, these hard layers are more frequently found at the base of the snow pack in recent decades (Johansson et al. 2011). These findings relate to observations of more frequent winter thaws and rain-on-snow events (Shmakin 2010; Fig. G in the On-line supplementary material) that can have catastrophic consequences for animal populations. The observations also relate to heavy snowfall under relatively high temperatures and compression by later snowfall. In Canada, traditional knowledge records evidence of harder snow that impacts the construction of snow shelters 
(Walser 2009). In contrast, observations of recent changes in snow stratigraphy for northern Eurasia in general showed that interannual variability outweighed any possible trends (Golubev et al. 2008).

An ice layer at the bottom of the snowpack ("basal ice") is an important problem for Arctic grazing animals such as reindeer, caribou, musk ox, and small rodents such as lemmings, particularly if the ice layer forms early in the season and restricts access to forage for an extended period (Forchhammer and Boertmann 1993; Aanes et al. 2000; Solberg et al. 2001; Griffith et al. 2002). Basal ice layers can form at any time during the snow season from thaw events followed by subsequent refreezing. However, the data archive of Bulygina et al. (2010b) suggests that they tend to be more frequently encountered in spring. In Russia, the thickness of the basal ice layer has been routinely measured at 958 long-term stations since 1966 as part of the meteorological observing program (Bulygina et al. 2010b). Dangerous events for reindeer husbandry (DER) are reported by the Russian Meteorological Service when the basal ice layer is thicker than $5 \mathrm{~mm}$ over 10 consecutive days. A recent analysis of DER events in Russia since 1966 (Bulygina et al. 2010b) found a downward trend of about $5 \%$ per decade in the number of sites reporting DER events, mainly in response to a shorter and more intense snow melt season. Further analysis of DER frequency in the early winter period is required to determine if there are changes with potential impacts for grazing animals.

\section{Observed Changes in Albedo and Snowpack Chemistry: Black Carbon Effects}

Snow is the most reflective natural surface on Earth, with albedo typically $70-80 \%$ for the freshly fallen snow. However, albedo gradually decreases with snow aging and contamination by external materials that accumulate in the snowpack. Nevertheless, the decreased albedo of the older snow cover remains much higher than that of all underlying surfaces except ice. Because the albedo is so high, it can be reduced by even small amounts of dark impurities. Just a few parts-per-billion (ppb) of black carbon (soot) can reduce the albedo of snow by $1-4 \%$, as the black carbon strongly absorbs solar radiation (Warren and Wiscombe 1980, 1985; Flanner et al. 2007). The absorbed radiation is converted to internal energy that is re-emitted as heat to the surrounding snow or ice and air. Hence, deposition of black carbon and other aerosols, such as deposition from volcanoes, onto snow and ice surfaces can increase melt rates (although the study by Jones et al. (2005) on the climate effects of a "super volcanic eruption" suggested increasing snow cover in response to the cooling). Snow with black carbon, therefore, melts sooner in the spring and uncovers the darker underlying surface, causing an amplifying feedback on climate warming (Hansen and Nazarenko 2004; Grenfell et al. 2009).

Some black carbon emissions result from marine transportation and offshore fossil fuel extraction within the Arctic (Macdonald et al. 2005), activities which are likely to increase as sea ice retreats (see Meier et al. 2011 and Hovelsrud et al. 2011). However, sources of black carbon are primarily located outside the Arctic. The main source is biomass burning (Hegg et al. 2009; 2010); forest and agricultural fires as well as the burning of fossil fuels. Nevertheless, black carbon particles can travel long distances and are able to reach the Arctic in substantial quantities. Observations show a large seasonal cycle in atmospheric levels, with maximum concentrations in surface air during late winter and early spring and minimum values in late summer and early autumn (Sharma et al. 2006; Gong et al. 2010). Black carbon particles are typically hydrophobic when emitted, but age fairly rapidly to a hydrophilic state by mixing with other particles in the atmosphere. They are then deposited at the surface primarily by wet deposition, although dry deposition also plays a small but important role. Atmospheric residence times are generally about 3-8 days (Shindell et al. 2008). A typical mid-latitude snow crystal contains thousands of particles, including absorbing black carbon and mineral dust (Chylek et al. 1987).

Clarke and Noone (1985) measured black carbon in snow throughout the western Arctic. The cleanest snow is in Greenland, with about 2 ppb (Doherty et al. 2010). In regions sampled both by Clarke and Noone (1985) and by Doherty et al. (2010), the snow contained less black carbon in 2005-2010 than in 1983-1984. This result is consistent with the decline in atmospheric black carbon levels measured continuously at Alert since 1989 (Gong et al. 2010). Snow in the Russian Arctic sampled in the winters of 2007 and 2008 (Grenfell et al. 2009) showed higher values than elsewhere in the Arctic, typically in the range 20-30 ppb. The median background values were 15-25 ppb on or near the coasts of the Barents and Kara Seas and near a polynya located within the Laptev Sea. Values were 15-20 ppb on the Chukchi Peninsula, but only $5 \mathrm{ppb}$ in a fresh snowfall event at the end of April. Farther south and west, background levels were higher at $20-80 \mathrm{ppb}$ in the Sakha Republic and $40 \mathrm{ppb}$ on the Taymir Peninsula (Grenfell et al. 2009).

The change in albedo due to the presence of black carbon can have substantial effects on snow melt and atmospheric temperatures when large amounts of sunlight reach the snow surface-the 20-year global warming potential of black carbon is 2000 carbon dioxide equivalents (Hansen et al. 2007). The effects of black carbon are greatest in large, open areas and in late spring, summer, and early autumn. The albedo reduction also varies with 
the age of the snow, with older, larger-grained snow showing roughly three times the reduction of new, smallergrained snow (Warren and Wiscombe 1985). More broadly, by reducing the reflection of solar radiation to space, deposition of black carbon onto snow and ice leads to warming of the planet as a whole, resulting in increased melt rates of snow and ice. Model studies suggest that black carbon plays a very large role in spring snow melt, with about $20-30 \%$ greater melting than in simulations that do not include the effects of black carbon deposits (Flanner et al. 2007). Experiments suggest that emissions of black carbon and organic matter from fossil fuel combustion induce $95 \%$ as much loss of springtime snow cover over Eurasia as anthropogenic carbon dioxide (Flanner et al. 2009).

\section{PROJECTED CHANGES IN SNOW COVER AND ITS CHARACTERISTICS}

\section{Methodology to Predict Changes in Snow Cover and Characteristics}

The present (2009) ability of the scientific community to provide guidance on how Arctic snow cover will respond to climate change is limited by a number of issues. First, there is no systematic collection of pan-Arctic snow data for monitoring changing snow cover conditions and for developing and evaluating climate models. Second, for computational reasons, the CMIP3 suite of coupled climate models used relatively simple snow schemes that did not include many processes important for high-latitude snowpack evolution (Brun et al. 2008; Holko et al. 2008). In addition, Kattsov et al. (2007) showed that the CMIP3 models tended to overestimate precipitation over major river basins in the Arctic due to inadequate treatment of orography and biases in atmospheric and sea-ice circulation. Räisänen (2008) and Brown and Mote (2009) found that the CMIP3 model mean SWE climatology over the Northern Hemisphere agreed reasonably well with available observations. However, there is also recent evidence that the atmospheric circulation patterns and snow feedbacks in the CMIP3 models are unrealistic over high latitudes. For example, Hardiman et al. (2008) showed that none of the CMIP3 models were able to reproduce the observed strong correlations of Eurasian autumn snow extent to atmospheric wave activity and Northern Annular Mode (NAM) anomalies in the following winter. Also, Fernandes et al. (2009) noted that the CMIP3 models do not properly capture the spatial and temporal characteristics of Northern Hemisphere snow temperature sensitive regions documented by Groisman et al. (1994a). Inadequate representation of snow-albedo feedbacks may be contributing to this, as previously noted by $\mathrm{Qu}$ and Hall (2006).

In light of these limitations, it is unrealistic to expect GCMs (General Circulation Models) to provide highquality projections of future changes in snow cover over the Arctic region. However, they can provide an indication of large-scale changes in precipitation- and temperaturedependent snow cover variables, such as snow cover start and end dates and maximum winter accumulation, which are important for many applications. Changes in snow properties such as snow density, ice layers, and changes in spatial accumulation patterns require the use of moresophisticated models and downscaling approaches.

\section{Climate Model Projections of Changes in Snow Cover and Snow Water equivalent}

The response of Northern Hemisphere snow cover to climate change simulated by the CMIP3 models did not receive much attention in the IPCC Fourth Assessment (Solomon et al. 2007). Subsequently, Räisänen (2008) examined projected twenty-first century changes in the SWE for 20 of the CMIP3 global climate models and found that, while the simulated warming shortens the snow season in both autumn and spring in all of Eurasia and North America, SWE at the height of winter generally increased in the coldest areas and decreased elsewhere. Regions with increasing levels of SWE coincided with the position of the $-20^{\circ} \mathrm{C}$ isotherm in late twentieth century NovemberMarch mean temperature (Räisänen 2008) that covers the northernmost portions of both continents. Already, there is evidence of increasing snow depth over northern Eurasia (e.g., Kitaev et al. 2005; Bulygina et al. 2009) but less evidence of increased snow accumulation over the Canadian Arctic (Brown and Mote 2009).

Analysis of the model consensus pattern for change in maximum SWE (Brown and Mote 2009) (see On-line supplementary material-Fig. H) showed that the response consisted of three broad zones: with significant decreases at lower latitudes; a broad zone over mid-to-high latitudes, where changes were not statistically significant; and the northern zone of increasing levels identified by Räisänen (2008). The temporal evolution of the climate change response of SCD (On-line supplementary material-Fig. I) is different in that decreases dominate (no regions were identified where climate models show significant increases in SCD), with the earliest and largest decreases in SCD occurring in coastal regions of the continents. Taken together, these figures suggest different regional snow cover responses over the Arctic, with the largest and most rapid decreases both in SWE and SCD over Alaska, northern Scandinavia, and the Pacific coast region of Russia. 

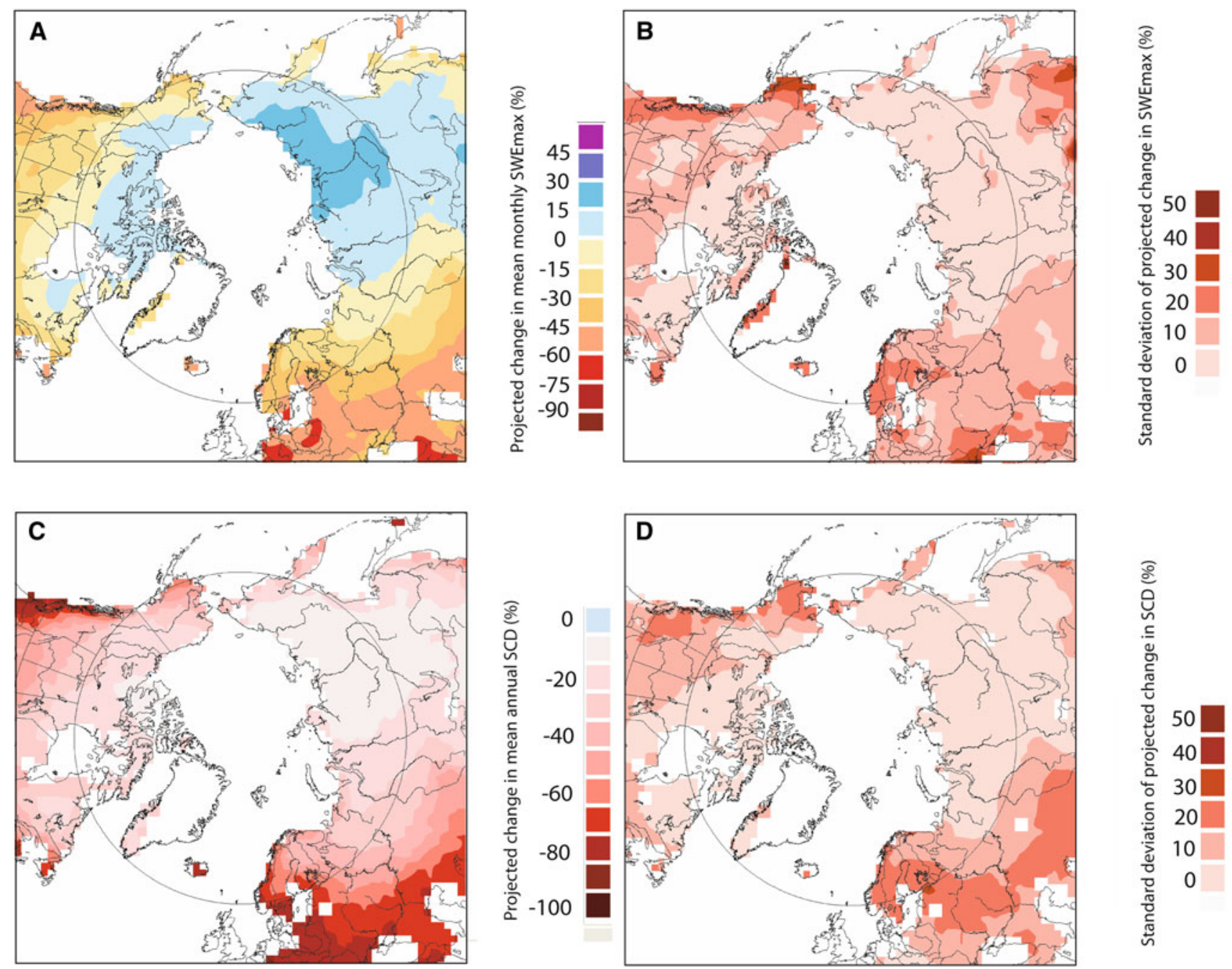

Fig. 6 Projected changes in maximum monthly SWE and annual SCD between 1970-1999 and 2049-2060 for six global climate models using the A2 emissions scenario. a Projected percentage change in maximum monthly SWE with $\mathbf{b}$ the standard deviation of the six projections shown. c Projected percentage change in mean

Projected changes in maximum monthly SWE ( $\left.\mathrm{SWE}_{\max }\right)$ and annual SCD for the 2049-2060 period versus 1970-1999 are provided in Fig. 6 from a composite of six of the highest resolution GCMs that meet the Arctic performance criteria applied in Overland et al. (2011). The choice of six models was based on the findings of Overland et al. (2011) that composites formed from the best-performing 5-7 models agreed more closely with observations than composites formed from fewer or more models. The six models used are CCSM3, CNRM, ECHAM5, GFDL, HADGem1, and MIROC32, and results are computed for the A2 emissions scenario. The projections suggest slight increases in $\mathrm{SWE}_{\max }(0-15 \%)$ over much of the Arctic, with the largest increases (15-30\%) over the Siberian sector. Annual SCD is projected to decrease by about annual SCD with $\mathbf{d}$ the standard deviation of the six projections. Seasonal snow cover information over the Greenland Ice Sheet is not available from the climate models. Source: computed from climate model projections presented by Brown and Mote (2009)

10-20\% over much of the Arctic, with the smallest decreases over Siberia $(<10 \%)$ and the largest decreases over Alaska and northern Scandinavia (30-40\%). The climate models project similar decreases in snow cover at the start and end of the snow season. The climate model standard deviations (right-hand panels in Fig. 6) show relatively high values of model consistency (standard deviations $<10 \%$ ) over the Arctic region for both $\mathrm{SWE}_{\max }$ and annual SCD with areas of lower model consistency over Alaska and western Europe. The process of interpolating climate model output with different resolutions to a standard grid contributes to higher model standard deviations in coastal mountain areas.

Some aspects of these climate model snow cover change projections may not be realistic. Brown and Mote (2009) 
found no evidence in the climate models of the accelerating reduction in high-latitude spring snow cover documented by Déry and Brown (2007) consistent with polar amplification of warming and an enhanced albedo feedback in spring. The muted spring response in the models could be due to a number of reasons, including lack of black carbon darkening (Flanner et al. 2009), inadequate snow-albedo treatments (Qu and Hall 2006), and wet-cold biases in models over high latitudes (Randall et al. 2007). The slower decrease in SCD over eastern Eurasia shown by the climate models is also inconsistent with observed trends and may be linked to difficulties in simulating the climate interactions of the Tibetan Plateau (Cui et al. 2007).

Snow cover changes are also likely to be much more complex in mountainous terrain than represented in the coarse-resolution GCM results. A sensitivity analysis of snow cover changes to increasing temperature and precipitation suggested a potentially complex elevation response of snow cover in mountain regions due to nonlinear interactions between the duration of the snow season and snow accumulation rates (Brown and Mote 2009). This non-linear response can be expected to contribute to regional-scale variability in the elevation response of snow cover to climate change, which will be modified by local factors such as lapse rate (rate of change with increasing altitude), aspect, topography, and vegetation.

\section{CONCLUSIONS}

Snow is a dominant feature of the Arctic landscape persisting for 8-10 months of the year. Its depth, extent, duration, timing, water equivalent, and stratigraphy have many consequences for the climate system, hydrology, permafrost, ecology, biogeochemical cycling, and socioeconomics. As snow characteristics are determined largely by temperature and moistures regimes that are changing in the Arctic, snow characteristics are also changing with farreaching consequences.

The amount and timing of snow cover are closely linked to temperature and moisture regimes that are changing in the Arctic. This is driving significant changes in the snow regime particularly during the spring season when snow cover disappeared earlier at an average rate of 3.4 days per decade over the pan-Arctic terrestrial region (excluding Greenland) during 1972-2009. This has contributed to an $18 \%$ reduction in MayJune Arctic snow cover extent over the 1966-2008 period. The changes are not uniform however, and the rates of change in SWE and SCD are observed to vary across the Arctic with the largest decreases occurring in maritime regions of the Arctic (Alaska, northern Scandinavia, and the Pacific coast region of Russia). New analyses show stronger decreases in Arctic coastal regions than inland. Snow depth changes have differed between North America and Eurasia over the past 50 years. Many regions of Eurasia exhibit increasing maximum in situ snow depth trends, while North American sites show decreasing trends. Furthermore, there is new evidence of changes in snowpack structure in some regions of the Arctic such as more frequent ice crust formation resulting from more frequent winter thaws and rain-on-snow events.

Climate model projections indicate decreases in the duration of snow cover of 10-20\% over most of the Arctic by 2050, with the smallest decreases over Siberia $(<10 \%)$ and the greatest losses over Alaska and northern Scandinavia (30-40\%). The earliest and largest decreases in SCD and accumulation are projected to occur over coastal regions of the continents in agreement with observed trends. Slight increases in maximum snow accumulation of $0-15 \%$ are projected over much of the Arctic with the largest increases (15-30\%) over the Siberian sector. The frequency and areal extent of rain-on-snow events are projected to increase over all regions of the Arctic over the next 50 years.

At present, there is no pan-Arctic dataset of in situ snow (e.g., SWE) and climate data for understanding large snow cover changes and their impacts. The current assessment has, by necessity, drawn on various types of information from numerous archives that are often not linked or compatible. As snow cover characteristics in the Arctic are among the most rapidly changing variables associated with ongoing climatic change, it is critical to invest time and resources in intercomparison and blending of the various types of information from existing and projected snow datasets within a context of social relevance.

Acknowledgments We wish to thank the various national funding agencies that made this review possible, specifically the Swedish Environmental Protection Agency (grant number 08/210) and the Swedish Research Council FORMAS (grant number 204-2009-45) who helped to directly support this publication. We also gratefully acknowledge the Arctic Monitoring and Assessment Program Secretariat and the SWIPA Integration Team in helping to produce the original SWIPA report and the various contributing SWIPA chapter authors including all contributing authors for the SWIPA snow chapter. Finally, we thank reviewers of the SWIPA snow chapter, particularly Barry Goodison.

\section{REFERENCES}

Aanes, R., B.E. Saether, and N.A. Oritsland. 2000. Fluctuations of an introduced population of Svalbard reindeer: The effects of density dependence and climatic variation. Ecography 23: 437-443.

AMAP. 2011. Snow, Water, Ice and Permafrost in the Arctic (SWIPA). Oslo: Arctic Monitoring and Assessment Programme (AMAP).

Atkinson, D.E., R. Brown, B. Alt, T. Agnew, J. Bourgeois, M. Burgess, C. Duguay, G. Henry, et al. 2006. Canadian cryospheric response to an anomalous warm summer: A synthesis of the 
climate change action fund project "The state of the arctic cryosphere during the extreme warm summer of 1998". Atmosphere-Ocean. 44: 347-375.

Bartsch, A., T. Kumpula, B.C. Forbes, and F. Stammler. 2010. Detection of snow surface thawing and refreezing in the Eurasian Arctic using QuikSCAT: Implications for reindeer herding. Ecological Applications 20: 2346-2358.

Brown, R., C. Derksen, and L. Wang. 2010. A multi-dataset analysis of variability and change in Arctic spring snow cover extent, 1967-2008. Journal of Geophysical Research 115: D16111. doi: 10.1029/2010JD013975.

Brown, R.D., and P.W. Mote. 2009. The response of Northern Hemisphere snow cover to a changing climate. Journal of Climate 22: 2124-2145.

Brun, E., R. Essery, and J. Cohen. 2008. Snow cover parameterizations and modeling. In Snow and climate, ed. R. Armstrong, and E. Brun, 125-180. Cambridge: Cambridge University Press.

Bulygina, O.N., P.Y. Groisman, and V.N. Razuvaev. 2010a. Snow cover characteristics over Northern Eurasia. Geophysical Research Abstracts 12: EGU2010-1460.

Bulygina, O.N., P.Y. Groisman, V.N. Razuvaev, and V.F. Radionov. 2010b. Snow cover basal ice layer changes over Northern Eurasia since 1966. Environmental Research Letters 5: 10.

Bulygina, O.N., V.N. Razuvaev, and N.N. Korshunova. 2009. Changes in snow cover over Northern Eurasia in the last few decades. Environmental Research Letters 4: 6.

Callaghan, T.V., F. Bergholm, T.R. Christensen, C. Jonasson, U. Kokfelt, and M. Johansson. 2010. A new climate era in the subArctic: Accelerating climate changes and multiple impacts. Geophysical Research Letters 37: 6.

Callaghan, T.V., M. Johansson, J. Key, T.D. Prowse, M. Ananicheva, and A. Klepikov. 2011a. Feedbacks and interactions: From the Arctic cryosphere to the climate system. In Arctic cryosphereChanges and impacts, ed. T.V. Callaghan, M. Johansson, and T.D. Prowse. Ambio 40(S1). doi:10.1007/s13280-011-0215-8.

Callaghan, T.V., M. Johansson, J. Key, T. Prowse, M. Ananicheva, and A. Klepikov. 2011b. Chapter 11.1 Synthesis of feedbacks and interactions: From the cryosphere to the climate systemeffects over various spatial and temporal scales. In Snow, Water, Ice and Permafrost in the Arctic (SWIPA). Oslo: Arctic Monitoring and Assessment Programme (AMAP).

Chylek, P., V. Srivastava, L. Cahenzli, R.G. Pinnick, R.L. Dod, T. Novakov, T.L. Cook, and B.D. Hinds. 1987. Aerosol and graphitic carbon content of snow. Journal of Geophysical Research-Atmospheres 92: 9801-9809.

Clarke, A.D., and K.J. Noone. 1985. Soot in the Arctic snowpack-a cause for perturbations in radiative-transfer. Atmospheric Environment 19: 2045-2053.

Cui, X.F., B. Langmann, and H.F. Graf. 2007. Summer monsoonal rainfall simulation on the Tibetan Plateau with a regional climate model using a one-way double-nesting system. SOLA 3: 49-52.

Derksen, C., R. Brown, and M. MacKay. 2008. Mackenzie basin snow cover: Variability and trends from conventional data, satellite remote sensing, and Canadian regional climate model simulations. In Cold region atmospheric and hydrologic studies, the Mackenzie GEWEX experience, ed. M.K. Woo, 213-240. Berlin: Springer.

Déry, S.J., and R.D. Brown. 2007. Recent Northern Hemisphere snow cover extent trends and implications for the snow-albedo feedback. Geophysical Research Letters 34: 6

Doherty, S.J., S.G. Warren, T.C. Grenfell, A.D. Clarke, and R.E. Brandt. 2010. Light-absorbing impurities in Arctic snow. Atmospheric Chemistry and Physics 10: 11647-11680.

Fernandes, R., H.X. Zhao, X.J. Wang, J. Key, X. Qu, and A. Hall. 2009. Controls on Northern Hemisphere snow albedo feedback quantified using satellite Earth observations. Geophysical Research Letters 36: L21702.

Flanner, M.G., C.S. Zender, P.G. Hess, N.M. Mahowald, T.H. Painter, V. Ramanathan, and P.J. Rasch. 2009. Springtime warming and reduced snow cover from carbonaceous particles. Atmospheric Chemistry and Physics 9: 2481-2497.

Flanner, M.G., C.S. Zender, J.T. Randerson, and P.J. Rasch. 2007. Present-day climate forcing and response from black carbon in snow. Journal of Geophysical Research-Atmospheres 112: D11202.

Forbes, B.C., and F. Stammler. 2009. Arctic climate change discourse: The contrasting politics of research agendas in the West and Russia. Polar Research 28: 28-42.

Forchhammer, M., and D. Boertmann. 1993. The muskoxen Ovibos moschatus in north and northeast Greenland-Population trends and the influence of abiotic parameters on population-dynamics. Ecography 16: 299-308.

Foster, J.L., D.A. Robinson, D.K. Hall, and T.W. Estilow. 2008. Spring snow melt timing and changes over Arctic lands. Polar Geography 31: 145-157.

Gerland, S., J.G. Winther, J.B. Orbaek, G.E. Liston, N.A. Oritsland, A. Blanco, and B. Ivanov. 1999. Physical and optical properties of snow covering Arctic tundra on Svalbard. Hydrological Processes 13: 2331-2343.

Golubev, V.N., M.N. Petrushina, and D.M. Frolov. 2008. Winter regime of temperature and precipitation as a factor of snowcover distribution and its stratigraphy. Annals of Glaciology 49: 179-186.

Gong, S.L., T.L. Zhao, S. Sharma, D. Toom-Sauntry, D. Lavoue, X.B. Zhang, R. Leaitch, and L.A. Barrie. 2010. Identification of trends and inter-annual variability of sulphate and black carbon in the Canadian High Arctic: 1981 to 2007. Journal of Geophysical Research-Atmospheres 115: D07305. doi:10.1029/2009JD01 2943,2010.

Grenfell, T.C., S.G. Warren, V.F. Radionov, V.N. Makarov, and S.A. Zimov. 2009. Expeditions to the Russian Arctic to survey black carbon in snow. EOS, Transactions of the American Geophysical Union 90: 386.

Griffith, B., D.C. Douglas, N.E. Walsh, D.D. Young, T.R. McCabe, D.E. Russell, R.G. White, R.D. Cameron, and K.R. Whitten. 2002. The Porcupine caribou herd. Biological Science Report, 8-37 pp. Alaska: U.S. Geological Survey, Biological Resources Division.

Groisman, P.Y., T.R. Karl, R.W. Knight, and G.L. Stenchikov. 1994. Changes of snow cover, temperature, and radiative heat-balance over the Northern Hemisphere. Journal of Climate 7: $1633-1656$.

Groisman, P.Y., R.W. Knight, V.N. Razuvaev, O.N. Bulygina, and T.R. Karl. 2006. State of the ground: Climatology and changes during the past 69 years over northern Eurasia for a rarely used measure of snow cover and frozen land. Journal of Climate 19: 4933-4955.

Hansen, J., and L. Nazarenko. 2004. Soot climate forcing via snow and ice albedos. Proceedings of the National Academy of Sciences of the United States of America 101: 423-428.

Hansen, J., M. Sato, P. Kharecha, G. Russell, D.W. Lea, and M. Siddall. 2007. Climate change and trace gases. Philosophical Transactions of the Royal Society A-Mathematical Physical and Engineering Sciences 365: 1925-1954.

Hardiman, S.C., P.J. Kushner, and J. Cohen. 2008. Investigating the ability of general circulation models to capture the effects of Eurasian snow cover on winter climate. Journal of Geophysical Research-Atmospheres 113: 9.

Hegg, D.A., S.G. Warren, T.C. Grenfell, S.J. Doherty, and A.D. Clarke. 2010. Sources of light-absorbing aerosol in Arctic snow 
and their seasonal variation. Atmospheric Chemistry and Physics 10: 10923-10938.

Hegg, D.A., S.G. Warren, T.C. Grenfell, S.J. Doherty, T.V. Larson, and A.D. Clarke. 2009. Source attribution of black carbon in Arctic snow. Environmental Science and Technology 43: 4016-4021.

Holko, L., K. Rubinstein, A. Shmakin, and Z. Kostka. 2008. Simulation of snow cover characteristics in atmospheric general circulation models and evaluation of simple schemes for simulation of snow water equivalent. Paper presented at transport of water, chemicals and energy in the soil-plantatmosphere system. 16th International Poster Day, 205-212, Bratislava.

Hovelsrud, G.K., B. Poppel, B Van Oort, and J. Reist. 2011. Chapter 10. Arctic societies, cultures, and peoples in a changing cryosphere. In Snow, Water, Ice and Permafrost in the Arctic (SWIPA). Oslo: Arctic Monitoring and Assessment Programme (AMAP)

Jones, G.S., J.M. Gregory, P.A. Stott, S.F.B. Tett, and R.B. Thorpe. 2005. An AOGCM simulation of the climate response to a volcanic super-eruption. Climate Dynamics 25: 725-738.

Kattsov, V.M., J.E. Walsh, W.L. Chapman, V.A. Govorkova, T.V. Pavlova, and X.D. Zhang. 2007. Simulation and projection of arctic freshwater budget components by the IPCC AR4 global climate models. Journal of Hydrometeorology 8: 571-589.

Kitaev, L.M., V.N. Razuvaev, R. Heino, and E. Forland. 2006. Duration of snow cover over Northern Europe. Russian Meteorology and Hydrology, 95-100. New York: Allerton Press (In Russian with English summary).

Kitaev, L., E. Førland, V. Razuvaev, O.E. Tveito, and O. Krueger. 2005. Distribution of snow cover over Northern Eurasia. Nordic Hydrology 36: 311-319.

Kohler, J., O. Brandt, M. Johansson, and T. Callaghan. 2006. A longterm Arctic snow depth record from Abisko, northern Sweden, 1913-2004. Polar Research 25: 91-113.

Macdonald, R.W., T. Harner, and J. Fyfe. 2005. Recent climate change in the Arctic and its impact on contaminant pathways and interpretation of temporal trend data. Science of the Total Environment 342: 5-86.

Meier, W.N., S. Gerland, M.A. Granskog, J.R. Key, C. Haas, G.K. Hovelsrud, K. Kovacs, A. Makshtas, et al. 2011. Chapter 9. Sea Ice. In Snow, Water, Ice and Permafrost in the Arctic (SWIPA). Oslo: Arctic Monitoring and Assessment Programme (AMAP).

Mekis, E., and W.D. Hogg. 1999. Rehabilitation and analysis of Canadian daily precipitation time series. Atmosphere-Ocean 37: 53-85.

Min, S.K., X.B. Zhang, and F. Zwiers. 2008. Human-induced arctic moistening. Science 320: 518-520.

Overland, J.E., M. Wang, J.E. Walsh, J.H. Christensen, V.M. Kattsov, and W.L. Chapman. 2011. Chapter 3. Climate Model Projections for the Arctic. In Snow, Water, Ice and Permafrost in the Arctic (SWIPA). Oslo: Arctic Monitoring and Assessment Programme (AMAP).

Popova, V.V. 2004. Structure of multi-year variations of the snow cover depth in North Eurasia. Russian Meteorology and Hydrology 8: 78-88 (In Russian with English summary).

Popova, V. 2007. Winter snow depth variability over northern Eurasia in relation to recent atmospheric circulation changes. International Journal of Climatology 27: 1721-1733.

Qu, X., and A. Hall. 2006. Assessing snow albedo feedback in simulated climate change. Journal of Climate 19: 2617-2630.

Radionov, V.F., E.I. Aleksandrov, V.R. Bayborodova, N.N. Bryazgin, and A.A. Dement'ev. 2004. Long-term changes of snow cover period in the Arctic. Data of Glaciological Studies 97: 136-142 (in Russian with English summary).
Radionov, V.F., N.N. Bryazgin, and E.I. Aleksandrov. 1996. The snow cover of the Arctic Basin. Gidrometeoizdat., St. Petersburg. 124 pp (in Russian) (English translation available from Polar Science Center, University of Washington, Seattle, WA 98105; Tech. Rep. APL-UW, TR 9701).

Räisänen, J. 2008. Warmer climate: less or more snow? Climate Dynamics 30: 307-319.

Randall, D.A., R.A. Wood, S. Bony, R. Colman, T. Fichefet, J. Fyfe, V. Kattsov, A. Pitman, et al. 2007. Climate models and their evaluation. Climate Change 2007: The physical science basis. Contribution of Working Group I to the Fourth Assessment Report of the Intergovernmental Panel on Climate Change. Cambridge: Cambridge University Press.

Razuvaev, V.N., and O.N. Bulygina. 2006. Variations in snow characteristics over the Russian territory in recent decades. Paper presented at 1st Asia CliC symposium, 35-38, Yokohama, Japan.

Riseth, J.A., H. Tømmervik, E. Helander-Renvall, N. Labba, C. Johansson, E. Malnes, J.W. Bjerke, C. Jonsson, et al. 2010. Sámi traditional ecological knowledge as a guide to science: Snow, ice and reindeer pasture facing climate change. Polar Record 47: 202-217. doi:10.1017/S0032247410000434.

Serreze, M.C., M.M. Holland, and J. Stroeve. 2007. Perspectives on the Arctic's shrinking sea-ice cover. Science 315: 1533-1536.

Sharma, S., E. Andrews, L.A. Barrie, J.A. Ogren, and D. Lavoué. 2006. Variations and sources of the equivalent black carbon in the high Arctic revealed by long-term observations at Alert and Barrow: 1989-2003. Journal of Geophysical Research-Atmospheres 111: 15.

Shindell, D.T., M. Chin, F. Dentener, R.M. Doherty, G. Faluvegi, A.M. Fiore, P. Hess, D.M. Koch, et al. 2008. A multi-model assessment of pollution transport to the Arctic. Atmospheric Chemistry and Physics 8: 5353-5372.

Shmakin, A.B. 2010. Climatic characteristics of snow cover over North Eurasia and their change during the last decades. Ice and Snow 1: 43-57.

Solberg, E.J., P. Jordhoy, O. Strand, R. Aanes, A. Loison, B.E. Saether, and J.D.C. Linnell. 2001. Effects of density-dependence and climate on the dynamics of a Svalbard reindeer population. Ecography 24: 441-451.

Solomon, S., D. Qin, M. Manning, Z. Chen, M. Marquis, K.B. Averyt, M. Tignor and H.L. Miller (ed.), 2007. Climate Change 2007: The Physical Science Basis. Contribution of Working Group I to the Fourth Assessment Report of the Intergovernmental Panel on Climate Change, 2007. 996 pp. Cambridge University Press.

Trenberth, K.E., P.D. Jones, P. Ambenje, R. Bojariu, D. Easterling, A. Klein Tank, D. Parker, F. Rahimzadeh, et al. 2007. Observations: Surface and Atmospheric Climate Change. In The Physical Science Basis. Contribution of Working Group I to the Fourth Assessment Report of the Intergovernmental Panel on Climate Change, ed. S. Solomon, D. Qin, M. Manning, Z. Chen, M. Marquis, K.B. Averyt, M. Tignor and H.L. Miller. 235-336. Cambridge University Press Cambridge, United Kingdom and New York, NY, USA.

Walser, M.L. 2009. International Arctic Science Committee (Content Partner); Maggie L. Walser (Topic Editor). 2009. Nunavut climate change case study. In Encyclopedia of Earth, ed. C.J. Cleveland. First published in the Encyclopedia of Earth January 2, 2008; Last revised September 14, 2009. http://www.eoearth.org/article/ Nunavut_climate_change_case_study?topic $=49664$. Retrieved 24 Sep 2009.

Walsh, J.E., J.E. Overland, P.Y. Groisman, and B. Rudolf. 2011a. Chapter 2: Arctic climate: Recent variations. In Snow, Water, Ice and Permafrost in the Arctic (SWIPA). Oslo: Arctic Monitoring and Assessment Programme (AMAP). 
Walsh, J.E., J.E. Overland, P.Y. Groisman, and B. Rudolf. 2011 b. Ongoing climate change in the Arctic. In Arctic cryosphereChanges and impacts, ed. T.V. Callaghan, M. Johansson, and T.D. Prowse. Ambio 40(S1). doi:10.1007/s13280-011-0211-z.

Warren, S.G., and W.J. Wiscombe. 1980. A model for the spectral albedo of snow. II: Snow containing atmospheric aerosols. Journal of the Atmospheric Sciences 37: 2734-2745.

Warren, S.G., and W.J. Wiscombe. 1985. Dirty snow after nuclear war. Nature 313: 467-470.

\section{AUTHOR BIOGRAPHIES}

Terry V. Callaghan $(\bowtie)$ is a Distinguished Research Professor at the Royal Swedish Academy of Sciences and Professor of Arctic Ecology at the Universities of Sheffield, UK and Lund, Sweden. He specializes in arctic ecology, and climate and UV-B radiation impacts on arctic ecosystems.

Address: Royal Swedish Academy of Sciences, 10405 Stockholm, Sweden.

e-mail: terry_callaghan@btinternet.com

Margareta Johansson is a research scientist at the Department of Earth and Ecosystem Sciences, Lund University and at the Royal Swedish Academy of Sciences, Stockholm, Sweden. She specializes in permafrost dynamics in relation to climate change and its impact on ecosystems.

Address: Department of Earth and Ecosystem Sciences, Division of Physical Geography and Ecosystem Analyses, Lund University, Sölvegatan 12, 22362 Lund, Sweden.

e-mail: margareta.johansson@nateko.lu.se

Ross D. Brown is a research scientist with the Climate Research Division of Environment Canada located at the Ouranos Climate Consortium in Montreal, Canada. His research interests include documenting and understanding snow cover variability and change, the representation of snow processes in climate and hydrological models, and the validation of snow cover in regional and global climate models.

Address: Climate Research Division of Environment Canada, Ouranos Climate Consortium, c/o Ouranos, 550 Sherbrooke St. West, 19th Floor, Montreal, QC H3A 1B9, Canada.

e-mail: ross.brown@ec.gc.ca

Pavel Ya. Groisman is a Research Scientist with the Global Climate Applications Division of the National Climatic Data Center/NOAA, Asheville, North Carolina USA. His research interests include climate, data synthesis and analysis, the diagnosis of climate variations, and Arctic climate.

Address: NOAA/NESDIS National Climatic Data Center, VeachBaley Federal Building, 151 Patton Avenue, Asheville, NC 288015001, USA.

e-mail: Pasha.Groisman@noaa.gov

Niklas Labba is the leader of Gáisi Sámi Centre in Tromsø, Norway. His research interests include traditional Sámi ecological knowledge and reindeer herding economy.

Address: Gáisi Sámi Centre, Lakselvbukt, 9042 Laksvatn, Norway. e-mail:n.labba@gmail.com

Vladimir Radionov is the Head of the Department of Meteorology at the Arctic and Antarctic Research Institute, Saint Petersburg. His research interests include analysis and generalization of hydrometeorological and solar radiation data in both polar regions.

Address: AARI, 38 Bering Str., Saint Petersburg, The Russian Federation 199397.

e-mail: vradion@aari.ru
Roger G. Barry was Director of the National Snow and Ice Data Center, University of Colorado, Boulder from 1976 to 2008. He is Distinguished Professor Emeritus of Geography and Fellow Emeritus of the Cooperative Institute for Research in Environmental Sciences at the University of Colorado. He specializes in polar and mountain climatology, climate change, and cryospheric sciences. He is author with T.Y. Gan of "The Global Cryosphere: Past, present and future" (2011).

Address: NSIDC/CIRES, University of Colorado, Boulder, CO 80309-0449, USA.

e-mail: rbarry@nsidc.org

Olga N. Bulygina is Lead Scientist at the Department of Climatology at the All-Russian Institute for Hydrometeorological Information, Obninsk, Kaluga Region, The Russian Federation. Her research interests include climatic data quality control, archiving, synthesis, analysis, and dissemination for the territory of the Commonwealth of Independent States.

Address: Climatology Department, All-Russian Research Institute of Hydrometeorological Information-World Data Centre (RIHMIWDC), 6 Koroleva Street, Obninsk, Kaluga Region, The Russian Federation 249035.

e-mail: bulygina@meteo.ru

Richard L. H. Essery is a Reader in the School of GeoSciences at the University of Edinburgh with research interests in modeling and observation of land-atmosphere interactions in cold regions.

Address: School of Geosciences, University of Edinburgh, Edinburgh, UK.

e-mail: ressery@staffmail.ed.ac.uk

D. M. Frolov is a Research Scientist at the Laboratory of Snow Avalanches and Mudflows at Geographical Faculty of Moscow State University, Moscow, The Russian Federation. His research interests include regularities of snow cover formation and the processes in snow cover.

Address: Laboratory of Snow Avalanches and Mudflows, Faculty of Geography, Moscow State University, Leninskie Gory, 1, Moscow, The Russian Federation 119991.

e-mail: denisfrolovm@mail.ru

Vladimir N. Golubev is lead Scientist at the Laboratory of Snow Avalanches and Mudflows at Geographical Faculty of Moscow State University, Moscow, The Russian Federation. His research interests include: ice crystal formation in atmosphere, solid precipitation and snowfalls, modeling of vapor transfer and isotopic content of snow cover.

Address: Laboratory of Snow Avalanches and Mudflows, Faculty of Geography, Moscow State University, Leninskie Gory, 1, Moscow, The Russian Federation 119991.

e-mail: golubev@geol.msu.ru

Thomas C. Grenfell is Professor emeritus in the Department of Atmospheric Sciences at the University of Washington, Seattle, WA. $\mathrm{He}$ specialize in the interaction of solar, infrared, and microwave radiation with polar snow and ice masses and its implications for polar and global climate related problems.

Address: Department of Atmospheric Sciences, MS 351640, University of Washington, Seattle, WA 98195-1640, USA.

e-mail: tcg@atmos.washington.edu

Marina N. Petrushina is an Associate Professor at the Department of Physical Geography and Landscapes at Geographical Faculty of Moscow State University, Moscow, The Russian Federation. Her research interests include snow and landscapes. 
Address: Department of Physical Geography and Landscapes, Faculty of Geography, Moscow State University, Leninskie Gory, 1, Moscow, The Russian Federation 119991.

e-mail: mnpetrushina@mail.ru

Vyacheslav N. Razuvaev is a Head of Climatology Department of the All-Russian Research Institute of Hydrometeorological Information-World Data Centre (RIHMI-WDC). He specializes in investigation of climate change on the regional scale and creation of baseline data sets for climate research.

Address: RIHMI-WDC, 6, Korolev Str., Obninsk, Kaluga Region, The Russian Federation 249035.

e-mail: razuvaev@meteo.ru

David A. Robinson is a Professor at the Department of Geography at Rutgers, The State University of New Jersey. His research interests include regional to global snow cover kinematics and dynamics, interactions of snow cover with other climate elements, and the collection and archiving of accurate climatic data.

Address: Department of Geography, Rutgers University, 54 Joyce Kilmer Avenue, Piscataway, NJ 08854, USA.

e-mail: david.robinson@ rutgers.edu

Peter Romanov is a Research Scientist with the Office of Satellite Applications and Research of the National Environmental Satellite Data and Information Service (NESDIS)/NOAA, Camp Springs, Maryland USA. His research interests include processing and application of satellite observation data for land surface monitoring.

Address: NOAA/NESDIS World Weather Building Rm. 711, 5200

Auth Rd., Camp Springs, MD 20746, USA.

e-mail: Peter.Romanov@noaa.gov

Drew Shindell is a senior scientist at the NASA Goddard Institute for Space Studies in New York City. His research interests include radiative forcing and climate response, especially for short-lived gases and aerosols, and interactions between air quality and climate change.

Address: NASA Goddard Institute for Space Studies, 2880 Broadway, New York, NY 10025, USA.

e-mail: drew.t.shindell@nasa.gov
Andrey B. Shmakin is the head of Laboratory of Climatology at the Institute of Geography, Russian Academy of Sciences. His research interests include diagnosis of contemporary changes of climate and snow cover characteristics, numerical modeling of the soil-vegetation-snow-atmosphere heat/water transfer, and applied climatic research.

Address: Institute of Geography, 29 Staromonetny St., Moscow, The Russian Federation 119017.

e-mail: ashmakin@igras.ru

Sergey A. Sokratov is senior research scientist in Natural Risks Assessment Laboratory and in the Research Laboratory of Snow Avalanches and Debris Flows, Faculty of Geography, Lomonosov Moscow State University. His interests include mass and energy balance of the snow cover and physical processes in snow. The applied face of his research is the quantification of the snow-related natural hazards.

Address: Faculty of Geography, Natural Risks Assessment Laboratory, Moscow State University, GSP-1, Leninskiye Gory 1, Moscow, The Russian Federation 119991.

e-mail: sokratov@nral.org

Stephen Warren is Professor of Atmospheric Sciences, and of Earth \& Space Sciences, at the University of Washington in Seattle. His research interest is solar and infrared radiative properties of snow, sea ice, glacier ice, and clouds.

Address: Department of Atmospheric Sciences, and of Earth \& Space Sciences, University of Washington, Seattle, WA 98195-1640, USA. e-mail: sgw@uw.edu

Daquing Yang is an Associate Professor at the University of Alaska Fairbanks. His research interests include cold region hydro-climatology, snow hydrology, climate and climate change, and applications of remote sensing data/products in the high latitude regions.

Address: Water and Environmental Research Center, University of Alaska Fairbanks, Fairbanks, AK, USA.

e-mail: dyang3@alaska.edu 